\title{
The Effect Of Capital Structure, Earning Management, Profitability, Free Cash Flow And Environment Cost On Firm Value With Dividend Policy As Moderating Variables In Pharmaceutical Sub Sector Companies Listed On The 2007-2019 Indonesia Stock Exchange Period
}

\author{
Remila Aprilia Ginting \\ Economic and Business Faculty, Universitas Sumatera Utara, Medan, Indonesia \\ Email corresponding author: remilaginting1996@gmail.com
}

\begin{abstract}
Firm value is one of the branchmark of the success in firm management in its operation so that its customers will trust it. The objective of the research was to analyze the influence of capital structure, earnings management, profitability, free cash flow and environment cost on firm value in pharmacyl companies that carry out Initial Public Offering (IPO) policies for the period 2007-2019. It also tested the variable of dividend policy as moderating variable in this research model.The Population are companies that carry out an Initial Public Offering (IPO) policy for the period 2007-2019. The population of this study was 104, the sample selection method of this study used the purpoive sampling method with a total of 8 companies that met the criteria. The type of data used is secondary data and the data analysis technique used is cross sectional data analysis technique with the help of Eviews 10 software. The results of this study indicate that capital structure and earnings management have a significant positive effect on firm value, while profitability and environment cost have a significant positive effect on firm value. Negative and significant, and free cash flow has a negative and insignificant effect on firm value.
\end{abstract}

Keywords : Capital structure, Earnings Management, Profitability, Free Cash Flow, Environment Cost, Dividend policy, firm value

\section{INTRODUCTION}

In Indonesia, which has entered the era of globalization, the business world is required to continue to be competent in competition, especially in the pharmaceutical industry which processes raw materials into finished goods, so that they can continue to produce which will generate profits and avoid bankruptcy. The long-term goal of forming a company is to maximize the value of the company by increasing the prosperity of the owners or shareholders. By maximizing the value of the company, it is hoped that it will invite new investors to invest because a high value indicates that the prosperity of shareholders is also high. Maximizing the value of the company can be achieved through the implementation of the financial management function, where one financial policy or decision taken will affect other financial decisions and have an impact on company value (Sukirni, 2012). The factors that are thought to be able to influence the value of the company are capital structure, earnings management, profitability, free cash flow and environmental costs. The first factor is the capital structure, the following table shows the value of DER in pharmaceutical companies which shows that some companies experience unreasonable debt levels. 
Table 1. Debt to Equity Ratio (DER) for pharmaceutical sub-sector manufacturing

\begin{tabular}{|c|c|c|c|c|c|c|c|c|c|c|c|c|c|c|c|}
\hline $\mathrm{N}$ & KOD & COMPAN & \multicolumn{13}{|c|}{ Capital structure (X1) (DER) } \\
\hline $\mathrm{O}$ & $\mathrm{E}$ & Y & 2007 & 2008 & $\begin{array}{c}200 \\
9\end{array}$ & 2010 & 2011 & 2012 & 2013 & 2014 & 2015 & $\begin{array}{c}201 \\
6\end{array}$ & $\begin{array}{c}201 \\
7\end{array}$ & $\begin{array}{c}201 \\
8\end{array}$ & $\begin{array}{c}201 \\
9\end{array}$ \\
\hline 1 & $\begin{array}{c}\text { DVL } \\
\mathrm{A}\end{array}$ & $\begin{array}{c}\text { Darya- } \\
\text { Varia } \\
\text { Laboratori } \\
\text { a Tbk. }\end{array}$ & 0.28 & 0.27 & 0.41 & 0.33 & 0.27 & 0.27 & 0.30 & 0.28 & 0.41 & 0.42 & 0.47 & 0.41 & 0.40 \\
\hline 2 & INAF & $\begin{array}{c}\text { Indofarma } \\
\text { Tbk. }\end{array}$ & 2.46 & 2.25 & 1.44 & 1.36 & $\begin{array}{c}83.0 \\
1\end{array}$ & $\begin{array}{c}82.8 \\
4\end{array}$ & $\begin{array}{c}119.2 \\
8\end{array}$ & 1.11 & 1.59 & 1.4 & 1.91 & 2.1 & 1,96 \\
\hline 3 & KAEF & $\begin{array}{c}\text { Kimia } \\
\text { Farma } \\
\text { Tbk. }\end{array}$ & 0.53 & 0.53 & 0.00 & 0.49 & 0.43 & 0.52 & 0.44 & 7.97 & 7.82 & 5.89 & 5.44 & 2.62 & 1.48 \\
\hline 4 & KLBF & $\begin{array}{c}\text { Kalbe } \\
\text { Farma } \\
\text { Tbk. }\end{array}$ & 0.50 & 0.37 & 0.39 & 0.23 & 0.27 & 0.27 & 0.33 & 0.27 & 0.25 & 0.22 & 0.2 & 0.2 & 0.18 \\
\hline 5 & $\begin{array}{c}\text { MER } \\
\mathrm{K}\end{array}$ & $\begin{array}{c}\text { Merck } \\
\text { Tbk. }\end{array}$ & 1.66 & 1.23 & 0.83 & 0.86 & 0.85 & 0.91 & 1.02 & 1.01 & 1.27 & 1.37 & 1.54 & 2.07 & 2.25 \\
\hline 6 & PYFA & $\begin{array}{c}\text { Pryidam } \\
\text { Farma } \\
\text { Tbk. }\end{array}$ & 0.42 & 0.42 & 0.37 & 0.30 & 0.43 & 0.55 & 0.86 & 0.79 & 0.58 & 0.58 & 0.47 & 0.66 & 0.53 \\
\hline 7 & SCPI & $\begin{array}{c}\text { Merck } \\
\text { Sharp } \\
\text { Dohme } \\
\text { Pharma } \\
\text { Tbk. }\end{array}$ & 70.43 & $\begin{array}{l}22.9 \\
0\end{array}$ & 9.49 & $\begin{array}{l}18.2 \\
9\end{array}$ & $\begin{array}{l}13.4 \\
7\end{array}$ & $\begin{array}{l}23.2 \\
4\end{array}$ & 70.83 & $\begin{array}{l}- \\
31.04\end{array}$ & $\begin{array}{l}13.9 \\
8\end{array}$ & 4.95 & 2.79 & 2.26 & 1.3 \\
\hline 8 & TSPC & $\begin{array}{l}\text { Tempo } \\
\text { Scan } \\
\text { Pacific } \\
\text { Tbk. }\end{array}$ & 0.34 & 0.36 & 0.34 & 0.36 & 0.85 & 0.87 & 0.64 & 0.35 & 0.45 & 0.42 & 0.46 & 0.43 & 0.47 \\
\hline
\end{tabular}

companies listed on the Indonesia Stock Exchange (IDX) for the 2007-2019 period

Based on the results of the calculations in table 1.1, it shows that the level of Debt to Equity Ratio (DER) at SCPI companies in 2014 experienced a very large decline, namely -31.04. It can be said that this SCPI company experienced an unreasonable level of debt use. In SCPI's balance sheet report, long-term debt is greater than current debt, so this company will experience liquidity problems in the future, besides that the company's profit is also getting depressed due to having to finance the interest on the loan. The following is the Return on Equity (ROE) data for manufacturing companies in the pharmaceutical sub-sector listed on the Indonesia Stock Exchange.

The second factor is earnings management. According to research conducted by Adiwibowo (2018), one of the factors that affect firm value is earnings management. Earnings management or earnings management is a condition where the manager does not succeed in achieving the specified profit target, then the manager takes advantage of his flexibility and is allowed by accounting standards in preparing financial statements to modify reported earnings or is called earnings management.

In addition to information related to earnings management, the third factor that affects firm value is profitability. Profitability (Profitability) is the company's ability to generate profits, if the level of profitability of the company is high/increasing, the larger the company will also generate profits so that it has an influence on dividend distribution decisions. The management is trying to get as much income as possible in order to increase the ability to pay dividends. The greater the dividend payment, the higher the company's performance or value. Musabbihan and Purnawati (2018) research states that profitability is a very influential factor on firm value. An important indicator seen by investors in assessing the company's prospects is to see the extent to which the company's profitability has increased and grown. The following is a table of ROE for pharmaceutical sub-sector companies listed on the Indonesia Stock Exchange. 
Table 1.2. Return on Equity (ROE) of pharmaceutical sub-sector manufacturing companies listed on the Indonesia Stock Exchange (IDX) for the 2007-2019 period

\begin{tabular}{|c|c|c|c|c|c|c|c|c|c|c|c|c|c|c|c|}
\hline \multirow{2}{*}{$\begin{array}{l}\mathrm{N} \\
\mathrm{O}\end{array}$} & \multirow{2}{*}{$\begin{array}{l}\mathrm{CO} \\
\mathrm{DE}\end{array}$} & \multirow{2}{*}{$\begin{array}{c}\text { NAMA } \\
\text { PERUSAHAA } \\
\mathrm{N}\end{array}$} & \multicolumn{13}{|c|}{ Profitbilitys (X3) (ROE) } \\
\hline & & & $\begin{array}{c}200 \\
7\end{array}$ & $\begin{array}{c}200 \\
8\end{array}$ & $\begin{array}{c}200 \\
9\end{array}$ & $\begin{array}{c}201 \\
0\end{array}$ & $\begin{array}{c}201 \\
1\end{array}$ & $\begin{array}{c}201 \\
2\end{array}$ & $\begin{array}{c}201 \\
3\end{array}$ & $\begin{array}{c}201 \\
4\end{array}$ & $\begin{array}{c}201 \\
5\end{array}$ & $\begin{array}{c}201 \\
6\end{array}$ & $\begin{array}{c}201 \\
7\end{array}$ & $\begin{array}{c}201 \\
8\end{array}$ & 2019 \\
\hline 1 & $\begin{array}{l}\text { DV } \\
\text { LA }\end{array}$ & $\begin{array}{c}\text { Darya-Varia } \\
\text { Laboratoria } \\
\text { Tbk. }\end{array}$ & $\begin{array}{c}1.59 \\
\%\end{array}$ & $\begin{array}{c}1.66 \\
\%\end{array}$ & $\begin{array}{c}0.13 \\
\%\end{array}$ & $\begin{array}{c}17.3 \\
\%\end{array}$ & $\begin{array}{c}16.6 \\
1 \%\end{array}$ & $\begin{array}{l}17.6 \\
9 \%\end{array}$ & $\begin{array}{c}13.7 \\
5 \%\end{array}$ & $\begin{array}{c}8.41 \\
\%\end{array}$ & $\begin{array}{l}11.0 \\
8 \%\end{array}$ & $\begin{array}{l}14.0 \\
9 \%\end{array}$ & $\begin{array}{l}14.5 \\
3 \%\end{array}$ & $\begin{array}{l}13.5 \\
7 \%\end{array}$ & $\begin{array}{c}16.98 \\
\%\end{array}$ \\
\hline 2 & $\begin{array}{c}\text { INA } \\
\text { F }\end{array}$ & Indofarma Tbk. & $\begin{array}{c}0.03 \\
\%\end{array}$ & $\begin{array}{c}0.01 \\
\%\end{array}$ & $0 \%$ & $\begin{array}{c}0.04 \\
\%\end{array}$ & $\begin{array}{c}6.06 \\
\%\end{array}$ & $\begin{array}{c}6.52 \\
\%\end{array}$ & $\begin{array}{c}- \\
9.18 \\
\%\end{array}$ & $\begin{array}{c}0.2 \\
\%\end{array}$ & $\begin{array}{c}1.11 \\
\%\end{array}$ & $\begin{array}{c}- \\
3.02 \\
\%\end{array}$ & $\begin{array}{c}- \\
8.79 \\
\%\end{array}$ & $\begin{array}{c}- \\
7.14 \\
\%\end{array}$ & $\begin{array}{c}- \\
\% .16\end{array}$ \\
\hline 3 & $\begin{array}{l}\text { KA } \\
\text { EF }\end{array}$ & $\begin{array}{c}\text { Kimia Farma } \\
\text { Tbk. }\end{array}$ & $\begin{array}{c}0.05 \\
\%\end{array}$ & $\begin{array}{c}0.05 \\
\%\end{array}$ & $\begin{array}{c}0.06 \\
\%\end{array}$ & $\begin{array}{c}0.12 \\
\%\end{array}$ & $\begin{array}{c}0.13 \\
\%\end{array}$ & $\begin{array}{c}0.09 \\
\%\end{array}$ & $\begin{array}{c}0.10 \\
\%\end{array}$ & $\begin{array}{c}13.0 \\
6 \%\end{array}$ & $\begin{array}{l}13.5 \\
9 \%\end{array}$ & $\begin{array}{l}11.9 \\
6 \%\end{array}$ & $\begin{array}{l}12.8 \\
9 \%\end{array}$ & $\begin{array}{c}8.12 \\
\%\end{array}$ & $\begin{array}{c}- \\
0.17 \\
\%\end{array}$ \\
\hline 4 & $\begin{array}{l}\mathrm{KL} \\
\mathrm{BF}\end{array}$ & $\begin{array}{c}\text { Kalbe Farma } \\
\text { Tbk. }\end{array}$ & $\begin{array}{l}20.8 \\
4 \%\end{array}$ & $\begin{array}{l}19.5 \\
1 \%\end{array}$ & $\begin{array}{l}21.5 \\
5 \%\end{array}$ & $25 \%$ & $\begin{array}{c}23.3 \\
7\end{array}$ & $\begin{array}{c}24.0 \\
8\end{array}$ & $\begin{array}{c}23.1 \\
8\end{array}$ & $\begin{array}{c}21.7 \\
4\end{array}$ & $\begin{array}{c}18.8 \\
1\end{array}$ & $\begin{array}{l}18.8 \\
6 \%\end{array}$ & $\begin{array}{c}17.6 \\
6 \%\end{array}$ & $\begin{array}{l}12.5 \\
8 \%\end{array}$ & $\begin{array}{c}15.01 \\
\%\end{array}$ \\
\hline 5 & $\begin{array}{l}\text { ME } \\
\text { RK }\end{array}$ & Merck Tbk. & $\begin{array}{c}0.41 \\
\%\end{array}$ & $\begin{array}{c}0.03 \\
\%\end{array}$ & $\begin{array}{c}0.04 \\
\%\end{array}$ & $\begin{array}{c}0.06 \\
\%\end{array}$ & $\begin{array}{l}0.05 \\
9 \%\end{array}$ & $\begin{array}{c}25.8 \\
7 \%\end{array}$ & $\begin{array}{c}34.2 \\
5 \%\end{array}$ & $\begin{array}{l}32.7 \\
7 \%\end{array}$ & $\begin{array}{c}0.30 \\
\%\end{array}$ & $\begin{array}{c}0.26 \\
\%\end{array}$ & $\begin{array}{c}0.24 \\
\%\end{array}$ & $\begin{array}{c}1.89 \\
\%\end{array}$ & $\begin{array}{c}150.9 \\
9 \%\end{array}$ \\
\hline 6 & $\begin{array}{l}\text { PY } \\
\text { FA }\end{array}$ & $\begin{array}{c}\text { Pryidam Farma } \\
\text { Tbk. }\end{array}$ & $\begin{array}{c}2.6 \\
\%\end{array}$ & $\begin{array}{c}3.33 \\
\%\end{array}$ & $\begin{array}{c}0.05 \\
\%\end{array}$ & $\begin{array}{c}0.05 \\
\%\end{array}$ & $\begin{array}{c}0.06 \\
\%\end{array}$ & $\begin{array}{c}0.06 \\
\%\end{array}$ & $\begin{array}{c}0.07 \\
\%\end{array}$ & $\begin{array}{c}2.75 \\
\%\end{array}$ & $\begin{array}{c}3.05 \\
\%\end{array}$ & $\begin{array}{c}4.88 \\
\%\end{array}$ & $\begin{array}{c}6.55 \\
\%\end{array}$ & $\begin{array}{c}3.8 \\
\%\end{array}$ & $\begin{array}{c}0.07 \\
\%\end{array}$ \\
\hline 7 & $\begin{array}{l}\text { SCP } \\
\text { I }\end{array}$ & $\begin{array}{c}\text { Merck Sharp } \\
\text { Dohme Pharma } \\
\text { Tbk. }\end{array}$ & $\begin{array}{c}1.44 \\
\%\end{array}$ & $\begin{array}{c}0.79 \\
\%\end{array}$ & $\begin{array}{c}0.55 \\
\%\end{array}$ & $\begin{array}{c}- \\
0.66 \\
\%\end{array}$ & $\begin{array}{c}- \\
1.18 \\
\%\end{array}$ & $\begin{array}{c}- \\
0.99 \\
\%\end{array}$ & $\begin{array}{c}- \\
1.17 \\
\%\end{array}$ & $\begin{array}{c}1.42 \\
\%\end{array}$ & $\begin{array}{c}0.21 \\
\%\end{array}$ & $\begin{array}{c}0.58 \\
\%\end{array}$ & $\begin{array}{c}0.34 \\
\%\end{array}$ & $\begin{array}{c}0.25 \\
\%\end{array}$ & $\begin{array}{c}18.26 \\
\%\end{array}$ \\
\hline 8 & $\begin{array}{c}\text { TSP } \\
\text { C }\end{array}$ & $\begin{array}{l}\text { Tempo Scan } \\
\text { Pacific Tbk. }\end{array}$ & $\begin{array}{c}0.13 \\
\%\end{array}$ & $\begin{array}{c}0.14 \\
\%\end{array}$ & $\begin{array}{c}18.4 \\
6 \%\end{array}$ & $\begin{array}{l}18.4 \\
9 \%\end{array}$ & $\begin{array}{l}18.5 \\
8 \%\end{array}$ & $\begin{array}{c}18.7 \\
3 \%\end{array}$ & $\begin{array}{c}16.4 \\
3 \%\end{array}$ & $\begin{array}{c}14.1 \\
4 \%\end{array}$ & $\begin{array}{c}12.2 \\
0 \%\end{array}$ & $\begin{array}{c}11.7 \\
7 \%\end{array}$ & $\begin{array}{c}10.9 \\
7 \%\end{array}$ & $\begin{array}{c}8.15 \\
\%\end{array}$ & $\begin{array}{c}6.18 \\
\%\end{array}$ \\
\hline
\end{tabular}

Based on the results of the calculations in table 1.2, it shows that the level of Return on Equity (ROE) at INAF companies in 2016 to 2019 experienced negative values, namely $-3.02 \%$, $8.79 \%,-7.14 \%$ and $-5.16 \%$, and SCPI companies in 2010 to 2013 experienced negative values, namely $-0.66 \%,-1.18 \%,-0.99 \%$ and $-1.17 \%$. It can be said that INAF and SCPI companies are not good at generating income. his. INAF and SCPI companies have not been able to demonstrate the company's ability to generate net income available to owners or investors. For management or shareholders, Return on Equity (ROE) is very important because it is used as a measurement of shareholder value creation, where the higher the Return on Equity (ROE) ratio, the higher the company value. This will certainly attract investors to launch their funds in the company.

Determination of investment decisions is also based on how the funds are used to run projects that generate a positive net present value in order to provide benefits to the company so as to increase the value of the company. However, this fact is not always fulfilled, in public companies managers have an incentive to expand the company beyond the optimal size, even though the expansion is carried out on projects that have a negative net present value, so it is called a negative NPV. This overinvestment condition is carried out using internal funds generated by the company in the form of free cash flow or free cash flow (Pontiff \& Laurence, 2004:141)

The fourth factor is free cash flow, where the problem of free cash flow is driven by the more free cash flow that is owned and meanwhile the growth opportunity is relatively small (Michaely and Allen, 2016). If the free cash flow is used to carry out overinvestment activities or carry out projects with a negative NPV, it will certainly harm the shareholders. Therefore, to reduce this problem, it is possible to limit free cash flow in order to prevent managers from carrying out projects with negative NPV and prevent managers from acting on personal interests, most of which conflict with the interests of company owners or shareholders. These restrictions are usually carried out by reducing the amount of free cash flow (free cash flow). If free cash flow is limited, managers will tend to carry out projects with a positive NPV and reduce actions that can harm company owners which will have an impact on increasing firm value. Therefore, it is very important to pay attention to the free cash flow factor in an effort to increase the value of the company. In addition, the factor that investors need to pay attention 
to is the environmental cost, which as we know, environmental problems in Indonesia, considering the impact of poor environmental management is becoming more and more real. Environmental problems are also increasingly becoming a serious concern, both by consumers, investors and the government. Concern for the environment actually arises as a result of various encouragements from parties outside the company, including the government, consumers, and stakeholders. By minimizing environmental problems, companies can increase efficiency from the point of view of costs (environmental costs) and benefits or effects (economic benefits). The application of environmental accounting by various companies to produce quantitative assessments of the costs and impact of environmental protection on the quality performance and financial performance of companies.

Managers in maximizing the value of the company are responsible for finding sources of funds, making investment decisions (meaning what funds will be used for), and dividend policy (ie how much profit sharing is obtained that can maximize shareholder profits). Dividend policy is used as a mediation of the relationship between capital structure, earnings management, profitability, Free Cash Flow and Environmental Cost on firm value, because dividend policy is an integral part of corporate funding decisions concerning the company's internal spending so that it is known its influence on firm value or dividend prices. company. Dividend policy in a company is a complex matter because it involves the interests of many related parties.

\section{LITERATURE REVIEW}

\section{Signalling theory}

Signaling theory is a theory about the company's encouragement in providing information to external parties. The emergence of this impulse is caused by information asymmetry where internal parties have a lot of information compared to external parties (Sari \& Zuhrotun, 2006). Signal theory suggests about how a company should give signals to users of financial statements. This signal is in the form of information about what management has used to realize the owner's wishes. Signals can be in the form of promotions or other information stating that the company is better than other companies.

\section{Stakeholder Theory}

Stakeholder Theory is a theory regarding the rights of Stakeholders to provide company information with the aim that management can develop company value from the impact of company activities and for Stakeholders to reduce the risk of loss due to what will be caused by the relationship between the company and Stakeholders. Stakeholder theory considers the position of stakeholders who are considered powerful. This stakeholder group is a consideration for companies in disclosing or not disclosing information in financial statements. The stakeholder groups include shareholders, employees, customers, suppliers, creditors, government and society.

\section{Firm Company}

The main purpose of the company according to the theory of the firm is to maximize the wealth or value of the company. The value of the company is the income/perception of external parties, one of which is the investor on the level of success of the company which is associated with the stock price. The value of the company describes the condition of the company's achievement during the operating process. A company's achievement is described by an increase in the value of the company which reflects an increase in prosperity for shareholders, which can be seen from the profit earned per share invested. The value of the company is represented by the market value of the shares, meaning that the high market value of the shares 
reflects the high value of the company and vice versa (Puspitanigtyas, 2017). In this study, the value of the company is calculated by the following formula:

$$
\text { PBV: } \frac{\text { Share Price per Share }}{\text { Book Value Per Share }}
$$

\section{Capital Structure}

The capital structure aims to fund the company's operations by using debt or equity. Debt to equity ratio was chosen as the ratio to measure capital structure. Debt to equity ratio was chosen as a measurement of capital structure because as an assessment of high funding or capital originating from own capital or debt. Measurement of Capital Structure in this study uses the Debt to Equity Ratio (DER) with the following formula:

$$
\text { Debt to Equity Ratio }=\frac{\text { Total Liabilities }}{\text { Total Equity }}
$$

\section{Earnings management}

Earnings management is the independent variable in this study. The measurement of earnings management using discretionary accrual proxies calculated by the Healy model (1985) is tested by pair wise comparison of the mean total accruals, where aggressive financial reporting behavior or earnings management is assumed by Healy (1985) by comparing the results of the following equation:

$$
\begin{aligned}
& \mathrm{TAt}=(\text { Earn } 1-\mathrm{CFO}) \\
& \mathrm{DAC} 1=\mathrm{TAt} /\left(\mathrm{A}_{\mathrm{i}} \mathrm{t}-1\right)
\end{aligned}
$$

\section{Profitability}

Profitability is the ability of a company to generate profits in a certain period. Profitability is an indicator of a management's performance in managing the wealth of a company in the form of profits generated. The higher the company's ability to earn profits, the greater the return so that the value of the company is also getting better. In this study, the researchers used Return On Equity (ROE). Return On Equity (ROE) or often called own capital profitability is used to measure the company's ability to generate profits by utilizing the company's share capital. The following formula can be used to calculate Return On Equity (ROE):

$$
\mathrm{ROE}=\frac{(\text { Profit after tax })}{\text { Equity Capital }} \times 100 \%
$$

\section{Free Cash Flow}

Free cash flow is cash flow that is actually available for distribution to all investors (shareholders and debt owners) after the company has placed all of its investment in fixed assets, new products, and working capital needed to maintain ongoing operations (Brigham and Houston, 2009). Free cash flow is cash flow which is the remainder of funding all projects that generate a positive net present value (NPV) discounted at the relevant cost of capital level. (Jensen, 2014). Free cash flow is what often triggers the emergence of differences in interests between shareholders and managers.

This variable uses the following formulation:

$$
\text { FCFit }=\text { AKOit }- \text { PMit }- \text { NWCi }
$$

\section{Environment Cost}

Environmental Cost are costs incurred by the company to prevent environmental damage or improve environmental damage The more costs the company incurs, the less the company's profit. Measurement of environmental costs can be calculated by comparing the costs incurred by the company for its CSR activities with the company's profit Whino (2014), can be formulated as follows: 
Environmental Costs $=$ Prevention costs + detection costs + Internal failure costs + External failure costs

\section{Dividend Policy}

Dividend policy is basically the determination of the amount of profit or return that will be given to shareholders or the proportion of profits distributed to shareholders in an amount proportional to the number of shares owned. The amount of dividends can affect the stock price, if the dividend paid is high, then the stock price tends to be high so that the value of the company is also high and vice versa. In this study, researchers used the Divident Payout Ratio proxy in calculating dividend policy. Dividend Payout Ratio (DPR) is a ratio that shows the percentage of each profit earned which is distributed to shareholders in the form of cash. The formula used to calculate the Dividend Payout Ratio (DPR) in this study is as follows:

$$
\text { DPR: } \frac{\text { Dividen Per Share }}{\text { Earning Per Share }}
$$

\section{Conseptual Framework}

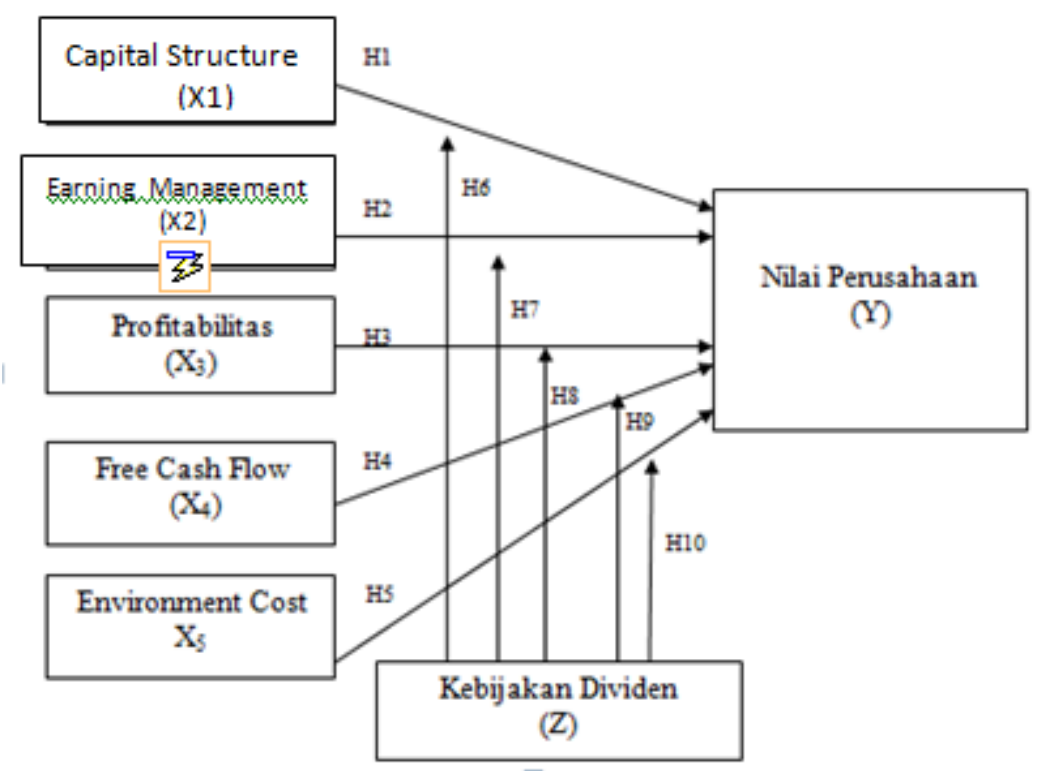

Figure 1. Conseptual Framework

\section{Research Hypothesis}

Hypothesis 1: Capital structure has a positive effect on firm value

Hypothesis 2: Earnings Management has a positive effect on firm value

Hypothesis 3: Profitability has a positive effect on firm value

Hypothesis 4: Free Cash Flow has a positive effect on firm value

Hypothesis 5: Environment Cost has a positive effect on firm value

Hypothesis 6: Dividend policy is able to moderate the effect of capital structure on firm value Hypothesis 7: Dividend policy is able to moderate the effect of earnings management on firm value

Hypothesis 8: Dividend policy is able to moderate the effect of profitability on firm value Hypothesis 9: Dividend policy is able to moderate the effect of free cash flow on firm value Hypothesis 10: Dividend policy is able to moderate the effect of environmental costs on firm value 


\section{RESEARCH METHODS}

This type of research is included in causal-associative research, namely research using the characteristics of the problem in the form of a causal relationship between two or more variables (Erlina, 2008). This study examines the effect of capital structure, earnings management, profitability, free cash flow and environment cost as independent variables on firm value as the dependent variable with dividend policy as a moderating variable. The population in this study are pharmaceutical companies listed on the Indonesia Stock Exchange for the period 2007-2019.

This research uses purposive sampling technique in determining the research sample. The criteria built in determining the sample are as follows:

1. Pharmaceutical companies listed on the Indonesia Stock Exchange in a row in 2007-2019.

2. The company publishes complete financial statements for the period December 31, 20072019 on the Indonesia Stock Exchange (IDX) website.

3. The company has complete financial statement data related to the research variables studied in the financial statements

\section{Research Result}

\section{Descriptive Statistical Analysis}

In testing the hypothesis, the coefficient of determination analysis will be carried out, simultaneous effect testing ( $F$ test), and partial effect testing ( $t$ test). Statistical values of the coefficient of determination, $\mathrm{F}$ test, and $\mathrm{t}$ test are presented in the following table:

\section{Statistical value of the Coefficient of Determination, F test, and t test}

\begin{tabular}{|l|r|r|r|r|}
\hline \multicolumn{1}{|c|}{ Variable } & Coefficient & Std. Error & t-Statistic & Prob. \\
\hline DER? & 0.032911 & 0.016048 & 2.050778 & 0.0430 \\
\hline DAC? & 0.178063 & 0.050716 & 3.510969 & 0.0007 \\
\hline ROE? & -0.073883 & 0.018442 & -4.006239 & 0.0001 \\
\hline FCF? & -0.0000014 & -0.0000065 & -0.219709 & 0.8266 \\
\hline BL? & -0.035632 & 0.015482 & -2.301560 & 0.0235 \\
\hline \multicolumn{1}{|c|}{ C } & 0.996108 & 0.230357 & 4.324191 & 0.0000 \\
\hline R-squared & $\mathbf{0 . 2 0 6 1 9 8}$ & Mean dependent var & 0.442446 \\
\hline Adjusted R-squared & 0.164854 & S.D. dependent var & 1.856974 \\
\hline S.E. of regression & 1.697020 & Akaike info criterion & 3.952647 \\
\hline Sum squared resid & 276.4682 & Schwarz criterion & 4.107057 \\
\hline Log likelihood & -195.5850 & Hannan-Quinn criter. & 4.015173 \\
\hline F-statistic & 4.987383 & Durbin-Watson stat & 2.280351 \\
\hline Prob(F-statistic) & $\mathbf{0 . 0 0 0 4 1 9}$ & & \\
\hline
\end{tabular}

\section{Coefficient of Determination Test}

Based on the table above, it is known that the value of the coefficient of determination (RSquared) is 0.206198 which means 0.206198 or $(20.61 \%)$ the independent variables, namely DER, DAC, ROE, FCF, BL are able to explain or describe the value of the company's subsector. Pharmacies listed on the Indonesia Stock Exchange, the remaining 79.39\% is influenced by other factors not included in this study.

\section{F Uji test}

Based on the table above, it is known that the Prob value. (F-statistics), which is 0.000419 $<0.05$, it can be concluded that all independent variables, namely DER, DAC, ROE, FCF, BL simultaneously, have a significant effect on the PBV variable. 


\section{T Uji test}

Based on the table of t-test results above, it can be seen that DER has a positive effect on PBV, with a regression coefficient value of 0.03 and significant with a Prob value. $0.0430<0.05$. So that DER has a positive and significant effect on PBV. It is known that DAC has a positive effect on PBV, with a regression coefficient of 0.17 and significant with a Prob value. 0.0007 $<0.05$. So that DAC has a positive and significant effect on PBV. It is known that ROE has a negative effect on PBV, with a regression coefficient value of -0.07 and significant with a Prob value. $0.0001<0.05$. So that ROE has a negative and significant effect on PBV. It is known that FCF has a negative effect on PBV, with a regression coefficient value of -0.0000014 , but not significant with the value of Prob. 0.8266>0.05. So that FCF has a negative effect on PBV, but not significant. It is known that BL has a negative effect on PBV, with a regression coefficient of -0.03 and significant with a Prob value. $0.0235<0.05$. So that

BL has a negative and significant effect on PBV.

Interaction Moderation Test

\begin{tabular}{|c|r|r|r|r|}
\hline Variable & Coefficient & Std. Error & t-Statistic & Prob. \\
\hline Z & 0.022700 & 0.004946 & 4.589789 & 0.0000 \\
\hline X1Z & 0.000564 & 0.002655 & 0.212467 & $\mathbf{0 . 8 3 2 2}$ \\
\hline X2Z & 0.032654 & 0.033020 & 0.988905 & $\mathbf{0 . 3 2 5 4}$ \\
\hline X3Z & 0.001471 & 0.000521 & 2.823316 & $\mathbf{0 . 0 0 5 9}$ \\
\hline X4Z & 0.00002 & 0.0000039 & 5.123429 & $\mathbf{0 . 0 0 0 0}$ \\
\hline X5Z & 0.000222 & 0.002744 & 0.081076 & $\mathbf{0 . 9 3 5 6}$ \\
\hline C & 0.374505 & 0.232838 & 1.608434 & 0.1112 \\
\hline
\end{tabular}

Based on the table of interaction moderation results above, the results of this study show an alpha of $5 \%$ or $(0.05)$ namely $\mathrm{z}$ which is the interaction between policies on capital structure which has a Prob value of $X 1 Z$ is $0.8322>$ a significance level of 0.05 , and the value Prob of $\mathrm{X} 2 \mathrm{Z}$ is $0.3254>0.05$ level of significance. And the Prob value of $\mathrm{X} 5 \mathrm{Z}$ is $0.9356>0.05$ level of significance, it is concluded that DPR is not significant in moderating the effect of DER, DAC, and BL on PBV, so h6, h7, h10 are rejected. The Prob value of X3Z is $0.0059<0.05$ significance level, and the Prob value of $\mathrm{X} 4 \mathrm{Z}$ is $0.0000<0.05$ significance level, it can be concluded that DPR is significant in moderating the effect of ROE, FCF on PBV, it can be concluded that $\mathrm{h} 8, \mathrm{~h} 9$ accepted

\section{DISCUSSION}

\section{Effect of Capital Structure on Firm Value}

The test results on the first hypothesis in this study indicate that the capital structure variable has a significant positive effect on firm value. This means that the use of debt gives a positive sign of a company that can make investors appreciate the value of shares greater than the value recorded on the company's balance sheet. The results of this study support and are in line with several studies from Muslimin et al. (2015), Pratiwi et al. (2016); Pangulu. (2014); Hirdinis (2019), and Diannisa et al. (2019) states that the capital structure (DER) has a positive effect on firm value. In accordance with the Signaling theory which states that when a company uses internal funds to fund its business, investors will see it as a significant positive signal because the investor's perception when the company uses debt means that the company has the ability to increase capacity and pay debts. This is in line with research from Kusumawati and Rosady (2018) which states that capital structure has a positive effect on firm value, where companies with high debt get tax savings from the interest paid so that the firm value is high. 


\section{The Effect of Earnings Management on Firm Value}

In testing the second hypothesis, it shows that the earnings management variable has a positive and significant effect on firm value in the pharmaceutical sub-sector manufacturing companies listed on the Indonesia Stock Exchange. Thus this proves that earnings management actions taken by managers can have an impact on the survival of the company. Where investors will give an unfavorable reaction which will have an impact on the decline in the value of the company which is reflected in the company's stock price. This is in accordance with the theory that the existence of asymmetry between management and company owners provides an opportunity for managers to carry out earnings management to increase firm value. Earnings management carried out by managers is carried out by intervening in the preparation of financial statements based on accrual accounting on the company's fundamental factors. The results of this study are consistent with the research of Indriani et al. (2014) stated that earnings management has a positive and significant effect on firm value. As we know that the signal theory, where the manager will try to give a good signal for the owners of the company's stock. Earnings management is a manager's effort in manipulating financial statements to make it look good and can affect the views of company owners regarding company performance.

\section{The Effect of Profitability on Firm Value}

Partial test results in this study indicate that profitability has a negative and significant effect on firm value. From this research it can be interpreted that this profitability indicates an increase in profitability will reduce the value of the company. Although the company experienced an increase in profits, the company used these profits for retained earnings and not distributed to shareholders. So investors consider it a negative signal and have an impact on the value of the company. This is in line with the results of Herawati (2013) research showing that profitability has a negative and significant effect on firm value.

\section{The Effect of Free Cash Flow on Firm Value}

The results of testing the fourth hypothesis indicate that the Free Cash Flow variable has a negative but not significant effect on firm value. This can be caused by investors considering companies that generate profits and pay dividends as a signal of an increase in company value rather than free cash flow. This is evidenced by the results of this study which states that profitability and dividend payments can increase firm value. Free cash flow in pharmaceutical companies listed on the IDX has a very low average so that the influence of free cash flow on company value is negative. This negative effect shows that if the company's free cash flow is low, it will increase the value of the company. This is because the company's free cash flow used for investment has a positive net present value or return.

\section{The Influence of Environment Cost on Firm Value}

The results of testing the fifth hypothesis indicate that the environmental cost variable has a significant negative effect on firm value. The results of the environmental cost analysis with the company value in this study support the research conducted by Lasmin \& Nuzula (2012). Lasmin and Nuzula (2012) conducted a study to see the relationship between environmental costs and company value. Lasmin \& Nuzula (2012:23) stated that the high environmental cost did not determine the positive results in the market reaction. Hassel, Nilsson \& Nyquist (2005:16) stated that the high level of environmental performance of the company is not considered a high value by investors. Pada saat perusahaan want menyajikan informasi lingkungan sebagai informasi tambahan perusahaan yang merupakan suatu sinyal agar menarik investor sebagai evidence bahwa perusahaan memiliki tingkat kinerja lingkungan yang high dan evidence bahwa perusahaan bertanggung jawab terhadap lingkungan, perusahaan juga harus menyadari bahwa hal tersebut akan membutuhkan dan menimbulkan environmental cost 
tall. When the company wants to have a high level of environmental performance, the company needs to incur costs so that this can be achieved. This can be considered by investors as a negative value because of the costs incurred by the investor as an impact on the winter season. Pengungkapan informasi lingkungan akan meningkatkan transparansi oleh berbagai pihak yang berkepentingan, termasuk in dalamnya transparasi jumlah biaya yang dikeluarkan oleh perusahaan terkait kinerja lingkungan perusahaan (environmnetal cost).

Hassel, Nilsson and Nyquist (2005: 16) menyatakan bahwa tingginya tingkat kinerja lingkungan perusahaan tidak dianggap sebagai high yang nilai oleh investor.Pada saat perusahaan want menyajikan informasi lingkungan sebagai informasi tambahanperusahaan yang merupakan suatu sinyal agar menarik investor sebagai bahwa evidence perusahaan memiliki tingkat kinerja high environmental support and evidence that the company is responsible for the environment, the company must also be aware of this high cost.

\section{CONCLUSION}

Based on the results of testing and discussion, the conclusion in this study is that the variables of capital structure and earnings management have a positive and significant effect on firm value. However, the variables of profitability, free cash flow and environment cost have a negative effect on the value of pharmaceutical sector companies listed on the Indonesia Stock Exchange. The results of this study indicate that the dividend policy does not significantly moderate the effect of capital structure, earnings management and environment cost on firm value. However, the dividend policy is able to moderate the relationship between profitability, free cash flow and firm value.

Suggestions that can be given to investors and potential investors who want to invest should invest in companies that have a good capital structure, profit management, profitability, free cash flow and environment cost that reflect the company has good corporate value so that it can guarantee returns on investment. implanted. Suggestions that can be given to further research are expected to re-examine the effect of other variables that are thought to affect firm value such as firm growth, firm size, Good Corporate Governance (GCG) variables. And furthermore, it is expected to re-examine the moderating variable, namely the dividend policy of other sector companies listed on the IDX with the aim of knowing whether the dividend policy can be used as a moderating variable on the company's overall value or not.

\section{REFERENCES}

Adiwibowo,Akmad Sigit. 2018. Pengaruh Manajemen Laba, Ukuran Perusahaan dan Leverage Terhadap Return Saham dengan Kebijakan Dividen sebagai Variabel Moderasi. Jurnal IlmiahAkuntansi UniversitasPamulang, 6(2): 203-222.

Aggarwal, D., \& Padhan, P. C. (2017). Impact of Capital Structure on Firm Value: Evidence from Indian Hospitality Industry. Theoretical Economics Letters, 07(04), 982-1000. https://doi.org/10.4236/tel.2017.74067

Allen, F. \& Michaely, R. (2016) "Payout Policy, Handbook of theEconomics ofFinance, in: G.M. Constantinides \& M. Harris \& R. M.Stulz (ed.)" Handbook ofthe Economics of Finance, edition 1:chapter 7: 337-429.

Alza, Reza Zulfikar dan Gde Satia Utama. 2018. Pengaruh Kebijakan Pendanaan, Kebijakan Investasi dan Kebijakan Dividen Terhadap Nilai Perusahaan dengan Risiko Bisnis sebagai Variabel Pemoderasi (Studi Empiris pada Perusahaan yang Tergabung dalam Indeks LQ45 2011-2015). JurnalRiset Akuntansi danBisnis Airlangga, 3(1): 396-415. 
Amelinda, Rita dan Happy Darmawan. 2018. Analisis Faktor Pengendali Konflik Keagenan Terhadap Nilai Perusahaan dengan Kebijakan Dividen sebagai Variabel Moderasi. Jurnal Manajemen, 22(2): 139-153.

Antoro, Ananto Dwi dan Sri Hermuningsih. 2018. Kebijakan Dividen dan Bi Rate sebagai Pemoderasi Likuiditas, Profitabilitas dan Leverage Terhadap Nilai Perusahaan Perbankan yang Terdaftar di BEI Tahun 2011-2017. Upajiwa Dewantara, 2(1): 58-75.

Ayu, D., \& Suarjaya, A. (2017). Pengaruh Profitabilitas Terhadap Nilai Perusahaan Dengan Corporate Social Responsibility Sebagai Variabel Mediasi Pada Perusahaan Pertambangan. E-Jurnal Manajemen Universitas

Burhanudin, dan Nuraini. 2018. Pengaruh Struktur Modaldan Profitabilitas Terhadap Nilai Perusahaan dengan Kebijakan Dividen sebagai Variabel Pemoderasi. Eco-Entrepreneurship, 3(2): 1-20.

Brigham, Eugen F dan Joel F Houston. 2003. Fundamentals of Financial Management: DasarDasar Manajemen Keuangan. Buku Satu Edisi Kesepuluh. Jakarta: Salemba Empat.

Brigham, Eugen F dan Ehrhardt, Michel C. 2009. Fundamentals of Financial Management: Theory and Practice (13 ${ }^{\text {th }}$ Edition). South- Western: Cengage Learning.

Bukit, R. B., Haryanto, B., \& Ginting, P. (2018). Environmental performance, profitability, asset utilization, debt monitoring and firm value. IOP Conference Series: Earth and Environmental Science, 122(1), 0-6. https://doi.org/10.1088/1755-1315/122/1/012137

Cahyani, R. I., T. Widiarti, dan J. L. Ferdina. 2015. Pengaruh Intellectual Capital Terhadap Profitabilitas pada Perusahaan Manufaktur yang Terdaftar di Bursa Efek Indonesia. Jurnal Akuntansi Perpajakan, 1(2): 1-18.

Chariri dan Imam Ghozali. 2007. Teori Akuntansi. Semarang : Badan Penerbit Universitas Diponegoro.

Cortez, Cudia (2016) Executive Stock Options and Earnings Management in

The Portuguese Listed Companies. RC-SAR, 15(1138-4891), 211-235.

Copeland, Weston. 2017, The Determinants of Capital Structure : Evidence

from Chinese Listed Companies, Economic change \& Restructuring, 38, 11-35.

Difah, Siti S. 2016. Analisis Faktor-Faktor Yang Mempengaruhi Dividend Payout Ratio Pada Perusahaan Bumn Yang Terdaftar Di Bursa Efek Indonesia Periode Tahun 2009-2015. Skripsi. Fakultas Ekonomi, Universitas Diponegoro. Semarang.

Durnev, Art \& Kim, Han. 2005. To Steal or Not to Steal: Firm Attributes, Denziana, Angrita dan Winda Monica. 2016. Analisis Ukuran Perusahaan dan Profitabilitas Terhadap Nilai Perusahaan (Studi Empiris pada Perusahaan yang Tergolong LQ45 di BEI Periode 20112014). JurnalAkuntansi dan Keuangan, 7(2): 241-254.

Dewi,Meutia. 2017. Analisis Rasio Keuangan untuk Mengukur Kinerja Keuangan PT Smartfren Telecom, Tbk. Jurnal Penelitian Ekonomi Akuntansi, (1)1: 1-14.

Dewi, Lindira Sukma, I Ketut Budiartha, dan I.D.G Dharma Saputra. 2017. Kebijakan Dividen Sebagai Variabel Moderasi Pengaruh Tax, Leverage dan Firm Size pada Earnings Management. E-JurnalEkonomi danBisnis Universitas Udayana, 6(1): 277-302.

Erica, Denny. 2018. Analisa Rasio Laporan Keuangan untuk Menilai Kinerja Perusahaan PT Kino Indonesia Tbk. Jurnal Ecodemica, 2(1): 12-20.

Erlina. (2011). Metodologi Penelitian, USU Press, Medan.

Fahmi, Muhammad dan Muhammad Derry Prayoga. 2018. Pengaruh Manajemen Laba Terhadap Nilai Perusahaan dengan Tax Avoidance sebagai Variabel Mediating. Liabilities JurnalPendidikan Akuntansi, 1(3): 225-238.

Fitriani, Kiki Liya, Fauji Sanusi dan Ika Utami W. 2017. Peran Kebijakan Dividen dalam Memediasi Nilai Perusahaan pada Perusahaan Manufaktur yangTerdaftardi Bursa Efek Indonesia Periode 2010-2015. TirtayasaEkonomika, 12(1): 96-112.

Frederik, P. G., Nangoy, S. C., \& Untu, V. N. (2015). Analisis Profitabilitas, Kebijakan Hutang Dan Price Earning Ratio Terhadap Nilai Perusahaan Pada Perusahaan Retail Trade Yang 
Terdaftar Di Bursa Efek Indonesia. Jurnal EMBA, 3(1), 1242-1253. https://doi.org/10.1210/jc.2017-00823

Gamayuni, R. R. (2015). The Effect Of Intangible Asset Financial Performance And Financial Policies On The Firm Value. International Journal of Scientific \& Technology Research, 4(1), 202-212.

Gitman, Lawrence J. 2003. Principles of Managerial Finance, Tenth Edition, International Edition Financial Series, Boston: Addison-Wesley.

Gunawan, I. M., Pituringsih, E., \& Widiastuty, E. (2019). Analisis Faktor-Faktor yang Mempengaruhi Nilai Perusahaan Manufaktur Yang Terdaftar di BEI Periode 2014-2016. EJurnal Akuntansi Universitas Udayana, 26(3), 2396-2422. https://doi.org/10.24843/EJA.2019.v26.i03.p27

Gunawan, Yanny Widiastuty, Wijiyanti Imelda. 2003. Analisis FaktorFundamental Dan Resiko Sistematik Terhadap Harga Saham Properti Di BEJ. Jurnal Akuntansi \& Keuangan Vol.5, No.2,Nopember $2003: 123-132$.

Hasnawaty, 2015. Faktor-Faktor Fundamental Keuangan Yangmempengaruhi Resiko Saham. Jurnal Bisnis \& Manajemen.Volume 2 No.3. Mei 2006 : 159 - 256 : Bandar Lampung.

Helmayunita, Nayang dan Vita Fitria Sari. 2013. Pengaruh Manajemen Laba dan Struktur Kepemilikan Perusahaan Terhadap Nilai Perusahaan. JurnalWRA, 1(1): 111-128

Horne, J. C., V. \& Wachowicz, John M. (2017). Fundamentals of Financial Management, PrinsipPrinsip Manajemen Keuangan. Jakarta: Salemba Empat.

Indasari, A. P., \& Yadnyana, I. K. (2018). Pengaruh Profitabilitas, Growth Opportunity, Likuiditas, dan Struktur Modal Pada Nilai Perusahaan. E- Jurnal Akuntansi, 22, 714. https://doi.org/10.24843/EJA.2018.v22.i01.p27

Indriani, Poppy, Jaka Darmawan dan Siti Nurhawa. 2014. Analisis Manajemen Laba Terhadap Nilai Perusahaan yang Terdaftar di Bursa Efek Indonesia (Studi Khusus: Perusahaan Dagang Otomotif). JurnalAkuntansi dan Keuangan, 5(1): 19-32.

Jensen, Michael C. And W.Meckling,"Theory of the firm : Manajerial Behavior Agency Cost, and Ownership Structure, "Jurnal of Finance Economics Vol. 3. No.4, 2014.

Julianti, D. (2015). Pengaruh Rasio Hutang (DER) Dan Profitabilitas (ROA) Terhadap Nilai Perusahaan (PBV) (Studi Kasus Pada Perusahaan Manufaktur Sub Sektor Otomotif Dan Komponen Yang Terdaftar Di Bursa Efek Indonesia Periode 2012-2014). Jurnal Ekonomi Universitas Kristen Indonesia, 104-122.

Jogiyanto. (2003). Teori Portofolio dan Analisis Investasi (Ed. 3). Yogyakarta: BPFE UGM.

Kallapur, S., \& Trombley, M. A. (1999). The Association Between Investment Opportunity Set Proxies and Realized Growth. Journal of Business Finance and Accounting.

Kasmir. (2015). Analisis Laporan Keuangan (1st ed.). Jakarta: Rajawali Pers.

Keismawati, Ni Putu Eka, Ni Luh Putu Wiagustini dan Made Pratiwi Dewi. 2017. Profitabilitas dan Leverage sebagai Prediktor Kebijakan Dividen dan Nilai Perusahaan (Studi pada Perusahaan Manufaktur di Bursa Efek Indonesia). Jagadhita:Jurnal Ekonomidan Bisnis, 3(1): 94-108.

Khoirunnisa,Fairus, Imas Purnamasari, dan Heraeni Tanuatmodjo. 2018. Pengaruh Struktur Modal Terhadap Nilai Perusahaan pada Perusahaan Tekstil dan Garmen. Journal of BusinessManagement Education, 3(2): 21-32.

Kohar, Andi dan Akramunnas. 2017. Pengaruh Struktur Modal dan Kebijakan Dividen Terhadap Nilai Perusahaan. Assets, 7(1): 1-16.

Kusumawati, Rita dan Irham Rosady. 2018. Pengaruh Sturuktur Modal dan Profitabilitas Terhadap Nilai Perusahaan dengan Kepemilikan Manajerial sebagai Variabel Moderasi. Jurnal Manajemen Bisnis, 9(2): 147-160.

Lewellen,Jonathan, 2014, Predicting returns with financial ratios,Journal of Financial Economics, Vol 74 : 209-235. 
Maghdalena,Risma. 2019. Analisis Pengaruh Profitabilitas, Likuiditas dan Penghindaran Pajak Terhadap Nilai Perusahaan dengan Transparansi sebagai Variabel Moderasi. Prosiding SeminarNasional Pakar Ke 2, 1-10.

Mahendra, A., L. G. S. Artini, A. A. G. Suarjaya. 2012. Pengaruh Kinerja Keuangan Terhadap Nilai Perusahaan Manufaktur di Bursa Efek Indonesia. Jurnal Manajemen, Strategi Bisnis, danKewirausahaan, 6(2): 130-138.Terhadap Nilai Perusahaan. Jurnal Benefita, 3(2): 227238.

Mandjar, S. L., \& Triyani, Y. (2019). Pengaruh Pertumbuhan Perusahaan, Profitabilitas, Likuiditas, Struktur Modal Dan Struktur Kepemilikan Terhadap Nilai Perusahaan. Jurnal Akuntansi, $8(1), 55-72$.

Manurung, S. D., Suhadak, \& Nuzula, N. F. (2014). the Influence of Capital Structure on Profitability and Firm Value. Jurnal Administrasi Bisnis, 7(2), 1-8.

Martini, Putri Dwi dan Ikhsan Budi Riharjo. 2014. Pengaruh Kebijakan Utang dan Profitabilitas terhadap Nilai Perusahaan: Kebijakan Dividen sebagai Variabel Pemoderasi. Jurnal Ilmu \& RisetAkuntansi, 3(2).

Martha, Lidya, Nur Ukhti Sogiroh, Maria Maghdalena, Febsri Susanti dan Yulia Syafitri. 2018. Profitabilitas dan Kebijakan Dividen

Mayoriza, Selviana dan Majidah. 2018. Pengaruh Struktur Modal, Profitabilitas dan Kebijakan Dividen Terhadap Nilai Perusahaan (Studi pada Perusahaan Non Keuangan yang Terdaftar dalam Indeks LQ45 Di Bursa Efek Indonesia Tahun 2012-2016). e-Proceeding ofManagement, 5(3): 3631-3639.

Mery, K. N., Zulbahridar, \& P. Kurnia .(2017). Pengaruh Likuiditas, Leverage, dan Profitabilitas,terhadap Nilai Perusahaan dengan Kebijakan Deviden sebagai Variabel Moderasi pada perusahaan pertambangan yang terdaftar di bursa efek Indonesia tahun 20112014. JOM Fekon, Vol.4 No.1, 2017.

Michael, H. R. (2019). The Effect Of Financial Ratio On Company Value With Inflation As A Moderation Variable. Jurnal Akuntansi, 23(1), 33. https://doi.org/10.24912/ja.v23i1.458

Minanari. 2018. Pengaruh Profitabilitas, Manajemen Laba Dan Kebijakan Deviden Terhadap Nilai Perusahaan (Studi Empiris pada Perusahaan Manufaktur yang Terdaftar Di Bursa Efek Indonesia Periode 2015 - 2016). Jurnal Profita, 11(1): 139-149.

Moniaga, F. (2013). Struktur Modàl, Profitabilitas Dan Struktur Biaya Terhadap Nilai Perusahaan Indutri Keramik. Jurnal EMBA, 1(4), 440.

Musabbihan,NellyAgustina dan Ni Ketut Purnawati. 2018. Pengaruh Profitabilitas dan Kebijakan Dividen Terhadap Nilai Perusahaan dengan Struktur Modal sebagai Pemediasi.E-Jurnal ManajemenUnud, 7(4): 1979-2009.

Nur, Triasesiarta. 2018. Pengaruh Growth Opportunity, Profitabilitas dan Struktur Modal Terhadap Nilai Perusahaan dengan Dividen sebagai Variabel Intervening pada Perusahaan Manufaktur yang Terdaftar Di BEI pada Periode 2014-2017. Jurnal ManajemenBisnis Indonesia, 5(3): 394-411.

Nugroho, W. C. (2017). Pengaruh Profitabilitas, Dividend Policy, Leverage Dan Keputusan Investasi Terhadap Nilai Perusahaan Konstruksi di BEI. Jurnal Mahasiswa Magister Akuntansi Universitas Airlangga, II(1), 104-122.

Nurhayati, M. (2013). Profitabilitas, Likuiditas Dan Ukuran Perusahaan Pengaruhnya Terhadap Kebijakan Dividen Dan Nilai Perusahaan Sektor Non Jasa. Jurnal Keuangan Dan Bisnis Universitas Mercu Buana, 5(2), 144-153.

Oktaviani, Marista, Asyidatur Rosmaniar Dan Samsul Hadi. 2019. Pengaruh Ukuran Perusahaan (Size) dan Struktur Modal Terhadap Nilai Perusahaan. Balace, 16(1): 102-111.

Oktaviani, Retno Fuji dan Anissa Amalia Mulya. 2018. Pengaruh Struktur Modal dan Profitabilitas Terhadap Nilai Perusahaan dengan Kebijakan Dividen sebagai Moderasi. Jurnal Akuntansi DanKeuangan, 7(2): 139-150.

Partami, Ni Luh Ningsih, Ni Kadek Sinarwati dan Nyoman Ari Surya Darmawan. 2015. Pengaruh Manajemen Laba Riil Terhadap Nilai Perusahaan dengan Corporate Governance sebagai 
Variabel Pemoderasi (Studi Empiris pada Perusahaan Manufaktur yang Terdaftar di Bursa Efek Indonesia). E-Journal S1 Ak UniversitasPendidikan Ganesha, 3(1): 1-12.

Pertiwi, T. K., \& Pratama, F. M. I. (2011). Pengaruh Kinerja Keuangan, Good Corporate Governance Terhadap Nilai Perusahaan Good And Beverage. Jurnal Manajemen Dan Kewirausahaan,14(2). https://doi.org/10.9744/jmk.14.2.118-127

Pinfold, John F., William R. Wilson dan Qiuli Li, 2001, Book-tomarket and size as determinants of returns in samll illiquid markets: the New Zealand Case, Financial Services Review, Vol 10: 291-302.

Pontiff, Jeffrey dan Lawrence D. Schall, 2004, Book-to-market ratios as predictors of market returns, Journal of Financial Economics, Vol 49: 141-16.

Phillips, Jhon, Morton Pincus, dan Sonja Olhoft Rego. 2003. Earning Management: New Evidence Based on Deferred Tax Expense. TheAccounting Review 78(2): 491-521.

Prasetyo, Wika Septian, Subchan Dan Sri Harjanto. 2017. Pengaruh Manajemen Laba Terhadap Kinerja Perusahaan dengan Good Corporate Governance sebagai Variabel Moderasi (Studi Kasus pada Perusahaan Manufaktur yang terdaftar di BEI Tahun 2011 - 2014). Jurnal EkonomiManajemen dan Akuntansi, 43(24): 34-48.

Puspitaningtyas, Zarah. 2017. Efek Moderasi Kebijakan Dividen dalam Pengaruh Profitabilitas Terhadap Nilai Perusahaan Manufaktur. Jurnal Akuntansi,Ekonomi dan Manajemen Bisnis, 5(2): 173-180.

Putri, Hana Tamara. 2019. Pengaruh Manajemen Laba Terhadap Nilai Perusahaan pada Industri Manufaktur yang Terdaftar di Bursa Efek Indonesia Periode 2015-2017. Jurnal Manajemen dan Sains, 4(1): 51-55.

Rahmantio, I., Saifi, M., \& Ferina, N. (2018). Pengaruh Debt to Equity Ratio, Return on Equity, Return on Asset dan Ukuran Perusahaan Terhadap Nilai Perusahaan ( Studi Pada Perusahaan Pertambangan Yang Terdaftar di Bursa Efek Indonesia Tahun. E-Jurnal Mahasiswa Universitas Brawijaya, 57(1), 151-159.

Rosdini, D. 2007. Pengaruh Free Cash Flow Terhadap Dividend Payout Ratio. Tesis. Universitas Padjajaran Bandung

Ross, Stephen A., Westerfield, Randolph W., Jaffe, Jeffrey \& Jordan Bradford D. 2009.Modern FinancialManagement (8th ed.). New York: McGraw-Hill.

Saksakotama, Paramita Hana dan Nur Cahyonowati. 2014. Determinan Integritas Laporan Keuangan Perusahaan Manufaktur Di Indonesia. DiponegoroJournal Of Accounting, 3(2): $1-13$.

Salempang, L. E., Sondakh, J. J., \& Pusung, R. J. (2016). Pengaruh Return On Asset, Debt To Equity Dan Pertumbuhan Penjualan Terhadap Nilai Perusahaan Pada Sektor Real Estate Dan Property Yang Terdaftar Di BEI Tahun 2013-2014. Jurnal Berkala Ilmiah Efisiensi, 16(03), 813-824.

Sambora, M. N., Handayani, S. R., \& Rahayu, S. M. (2014). Pengaruh Leverage Dan Profitabilitas Terhadap Nilai Perusahaan. Jurnal Administrasi Bisnis, 8(1), 1-10. https://doi.org/10.1017/CBO9781107415324.004

Sari \& Zuhrotun. (2006). Keinformatifan Laba di Pasar Obligasi dan Saham

Scott, William R. 2000. Financial Accounting Theory. New Jersey: Prentice Hall International, Inc.

Sisca. (2015). Pengaruh Leverage Dan Profitabilitas Terhadap Nilai Perusahaan Dengan Kebijakan Dividen Sebagai Variabel Moderasi Pada Perusahaan Manufaktur Yang Terdaftar Di BEI Tahun 2010-2014. Jurnal SULTANIST, 4(1), 1-9.

Subing., H., Wedi Rusmawan Kusumah, R., \& Gusni. (2017). An empirical analysis of internal and external factors of stock pricing: evidence from Indonesia. Problems and Perspectives in Management15(4), 178-187.

Sudiyatno, B., Puspitasari, E., \& Kartika, A. (2012). The Company's Policy, Firm Performance, and Firm Value: An Empirical Research on Indonesia Stock Exchange. American International Journal of Contemporary Research, 2(12), 30-40. 
Sukirni, D. (2012). Kepemilikan Manajerial, Kepemilikan Institusional, Kebijakan Dividen Dan Kebijakan Hutang. Accounting Analysis Journal, 1(2), 1-12.

Susanti, Yuli, Sri Mintarti dan Set Asmapane. 2018. Pengaruh Struktur Modal, Kinerja Keuangan Perusahaan, Ukuran Perusahaan dan Kualitas Auditor Eksternal Terhadap Nilai Perusahaan pada Perusahaan Manufaktur yang Terdaftar di Bursa Efek Indonesia. Akuntabel, 15(1): 111.

Tamonsang, Matheous, Maqbula Arochman dan Wiwik Herawati. 2014. Pengaruh Profitabilitas Terhadap Nilai Perusahaan dengan Kebijakan Deviden (Deviden Payout Ratio) sebagai Variabel Mediasi ( Studi Empiris padaSektor Perbankan yang Listing di PT. BEI ). Seminar Nasional InovatifII, 581-589.

Tunggal, Cecilia Aundrey dan Ngatno. 2018. Pengaruh Struktur Modal Terhadap Nilai Perusahaan dengan Ukuran dan Umur Perusahaan sebagai Variabel Moderator (Studi Kasus Tahun 2014-2016) pada Perusahaan Sub-Sektor Makanan dan Minuman yang Terdaftar di BEI. DiponegoroJournal of Social and Politic: 1-16.

Ulupui, IG.K.A. 2006. Analisis Pengaruh Rasio Likuiditas, Leverage,Aktivitas, Dan Profitabilitas Terhadap Return saham (Studi Pada Perusahaan Makanan Dan Minuman Dengan Kategori Industri Barang Konsumsi Di BEJ). Tesis. Fakultas Ekonomi UniversitasUdayana.

Ustman, Imam Subekti dan Abdul Ghofar. 2016. Analisis Pengaruh Manajemen Laba Terhadap Nilai Perusahaan sebelum dan saat Implementasi IFRS. Neo Bis, 10(1): 49-61.

Umobong,A. A (2015). Assessing The Impact Of Liquidity And Profitability Ratios On Growth Of Profits In Pharmaceutical Firms In Nigeria. European Journal of Accounting, Auditing and Finance Research, 3(10), 97-114.

Villiers EM, Fauquet C, Broker TR, et al. Classification of papillomaviruses. Virology 2017;234235.

Violeta, Achim Monica. 2007. Financial Analysis Of Companies On TheCapital Market, BabesBolyai University, Faculty of Economicsand Business Administration, Cluj-Napaco, Str. Teodor Mihali.

Wardoyo, \& Veronica, T. (2013). Pengaruh Good Coorporate Governance, Coorporate Social Responsibility \& Kinerja Keuangan Terhadap Nilai Perusahaan. Jurnal Dinamika Manajemen, 4(2), 132-149.

Wijaya, Bayu Irfandi dan Panji Sedana. 2015. Pengaruh Profitabilitas Terhadap Nilai Perusahaan (Kebijakan Dividen dan Kesempatan Investasi sebagai Variabel Mediasi). E-jurnal Manajemen Unud, 4(12): 4477-4500.

Wu Wei, Xu Jiuping. 2005. Fundamental analysis of stock price by artificial neural network model based on rough set theory. WorldJournal of Modelling and Simulation. Volume 2 (2006) No. 1, pp36-44 : P.R. China.

Yamaguchi, Keiko. 2009. Static And Dynamic Return On Corporate Environmental Investment: Empirical Evidence From Japan. Environmental and Resource Econimic Journal

https://journal.unnes.ac.id/sju/index.php/aaj/article/view/703

https://ojs.unud.ac.id/index.php/manajemen/article/view/16540

(https://www.ojk.go.id/id/kanal/pasar-modal/data-dan-statistik/statistik-pasarmodal/Documents/4.\%20Statistik\%20Desember\%20Mgg\%20ke-4\%202018.pdf) 